\title{
ABAD BARU PURBAKALA: MEMILIH ARAH MENENTUKAN PERAN PENELITIAN ARKEOLOGI DI MALUKU
}

\author{
New Century of Antiquity: The Direction and Role of Archaeological \\ Research in The Moluccas
}

\author{
Marlon NR Ririmasse \\ Balai Arkeologi Ambon-Indonesia \\ Jl. Namalatu-Latuhalat, Ambon 97118 \\ ririmasse@yahoo.com
}

Naskah diterima: 02-03-2015, direvisi: 21-08-2015; disetujui: 28-09-2015

\begin{abstract}
A year has passed since the celebration of 100th years of Indonesian archaeology. On June 14th 2013, this golden moment was commemorated by institutions and individuals. The nostalgic euphoria has been transformed into the festive spirit of various events. Ranging from seminars to exhibitions. From small gatherings to the colosal stages. There is a pride that rised from the establishment of this 100th anniversary. This article tries to discuss the current situation in the Indonesian archaeology by dissect the anatomy of archaeological research in the Moluccas Archipleago. The ideas disscussed will cover the review of archaeological research in the Moluccas historically; followed by observing the recent activities to understand the impacts of archaeological research for the region and its communities; and finally initiate the discussion on choosing the direction and the role of archaeological research for the academic and social purpose in the near future.
\end{abstract}

Kewords: Archaeology, The Direction and Role of Research, Moluccas

\begin{abstract}
Abstrak
Tak terasa hampir setahun telah dilewati sejak perayaan satu abad purbakala Nusantara. Tepat tanggal 14 Juni 2013 silam, momentum emas ini diperingati segenap insan arkeologi Indonesia. Gempita nostalgia dikemas menjadi semangat perayaan dalam berbagai kegiatan. Mulai dari seminar sampai pameran. Sekedar sukuran hingga pentas kolosal. Ada kebanggaan yang membuncah dari angka mapan usia ke-100. Kini pesta telah usai. Segalanya kembali senyap. Rasanya tepat untuk mulai merenung. Tentang makna menjadi lembaga dengan umur yang bahkan lebih sepuh dari negara. Memikirkan kembali kiprah pun capaian. Menemukenali kekurangan dan kendala. Adakah arkeologi akan terus mengalir dengan wawasan klasik business as usual? Ataukah memilih bercermin pada jernih kondisi kekinian dan bergegas membenahi diri? Makalah ini mencoba mengamati kondisi terkini arkeologi nasional dengan membedah anatomi penelitian arkeologi di Kepulauan Maluku dalam kerangka kronologis. Alur gagasan yang dibahas mencakup tinjauan atas rekam historis penelitian yang membentuk wajah arkeologi Maluku; dilanjutkan dengan mengamati aktivitas masa kini guna melihat aktualisasi studi arkeologi bagi kemajuan wilayah dan masyarakat; serta membuka ruang diskusi tentang memilih arah dan menentukan peran penelitian arkeologi bagi tujuan akademis dan sosial di masa mendatang.
\end{abstract}

Kata Kunci: Arkeologi, Arah dan Peran Penelitian, Maluku 
("Seorang arkeolog yang berkecimpung dalam studi mengenai benda-benda dari masa lalu, apabila ia merenung lebih jauh dan lebih dalam, maka ia akan menyadari bahwa esensi tentang semua yang dipelajari adalah tentang manusia, tentang spiritualitasnya, tentang daya-ciptanya, dan tentang ketrampilannya.")

(Herstel in Eigen Waarde: Monumentenzorg in Indonesie. Kempers, 1978: 9 )

\section{PENDAHULUAN}

Penggalan kalimat pengantar di atas dikutip dari buah pikir Bernet AJ Kempers. Arkeolog senior asal Negeri Belanda, sekaligus salah satu peletak dasar dunia akademis arkeologi Indonesia. Bagi para penggiat studi kepurbakalaan Asia Tenggara, Kempers dikenal melalui karya-karya akademisnya seperti The Ancient Indonesian Art (1959) dan Ageless Borobudur (1976). Karya klasik yang menjadi pustaka utama tentang kepurbakalaan Nusantara. Pesona gagasan Kempers ini kiranya tidak lepas dari latar belakang hidupnya. Dimana berbeda dengan ilmuwan Eropa tentang Indonesia yang lain, Kempers menghabiskan sekitar 50 tahun pertama usianya di Nusantara. Selama masa ini, Kempers bekerja sebagai Pustakawan di Royal Batavian Society atau kini dikenal sebagai Museum Nasional. Sekaligus menjadi pengajar sejarah budaya dan arkeologi di Jakarta dan Yogyakarta.

Bernet Kempers juga pernah memegang jabatan penting sebagai Kepala Jawatan Purbakala atau Oudheikundige Dienst. Institusi yang bertanggung jawab atas pengelolaan warisan budaya di Hindia Belanda. Peran ini menjadi sentral, karena pada masa itu, Kempers dihadapkan pada dua tantangan. Pertama, ia harus membangun kembali institusi yang sempat remuk pasca Perang Pasifik. Kedua, berada di masa peralihan penyerahan kedaulatan dari Hindia Belanda menjadi Indonesia, Kempers harus mengantar Jawatan Purbakala menemukan tempatnya di negara baru ini. Di tengah masa penuh ketidakpastian itu, Bernet Kempers melakukan tanggung jawab besarnya dengan sempurna.
Jawatan Purbakala, yang sempat nyaris mati suri selama masa pendudukan Jepang dihidupkan kembali. Ketika itu hanya bagian bangunan di Yogyakarta yang masih berfungsi di bawah pimpinan Suhamir. Unit-unit lain di Batavia tercerai berai dan tidak berfungsi. Memegang mandat yang diembannya, Kempers mempersatukan kembali unit bangunan di Yogyakarta dengan Institusi Induknya di Jakarta pada tahun 1951. Dalam keriuhan pemulihan Jawatan Purbakala, Kempers masih mencurahkan waktu, tenaga dan pemikirannya di ranah akademis. Mengajar arkeologi, membimbing generasi pertama calon akademisi arkeologi nasional.

Hasilnya, Kempers menutup masa baktinya di Indonesia dengan manis, ketika muridnya Soekmono, lulus sebagai doktorandus arkeologi pertama di Fakultas Sastra Universitas Indonesia, yang dua bulan pasca menerima gelar, diserahi tanggung jawab meneruskan kepemimpinan di Jawatan Purbakala menggantikan sang guru. Soekmono melanjutkan kepemimpinan Kempers pada tahun 1953 dan menakhodai lembaga ini hingga tahun 1973. Di bawah komando Soekmono, Dinas Purbakala bertumbuh pesat. Lembaga yang pada awalnya menjadi bagian dari Jawatan Kebudayaan, berkembang menjadi Direktorat Purbakala dan Sejarah hingga akhirnya menjadi Lembaga Purbakala dan Peninggalan Nasional.

Atas jasa ini, tak heran, wartawan senior P. Swantoro menyebutkan bahwa adalah berkat kepemimpinan Kempers, yang memang mencintai dunia kepurbakalaan Indonesia, kehidupan kembali Jawatan Purbakala, bukanlah sekedar nama (Swantoro, 2002: 101). Pantas kiranya jika kemudian penghargaan dan rasa hormat, disampaikan dengan sangat mengesankan oleh mendiang Soekmono dalam sebuah tulisan in memoriam di majalah BKI 1994, untuk mengenang sang guru yang berpulang pada 2 Mei 1992.

Kempers, kiranya merupakan satu di antara pribadi-pribadi hebat yang hadir dan jalin menjalin membentuk wajah studi 
kepurbakalaan di Nusantara. Kehadiran figurfigur pembelajar ini telah meletakkan dasar dan kerangka akademis bagi arkeologi Indonesia. Berada dalam kondisi politik yang relatif kusut di sebuah negara baru, dengan tekanan anti-kolonial yang semestinya mengemuka pada masanya, Kempers memilih tinggal dan memberikan kontribusi sentral yang menentukan arah dan peran arkeologi Indonesia di masa depan.

Kini tak terasa, usia tata-kelola kepurbakalaan Nusantara, telah mencapai lebih dari satu abad. Banyak hal yang telah dilewati selama bilangan seratus tahun tersebut. Keputusan-keputusan telah diambil oleh mereka yang mendapat mandat pada masanya. Membentuk wajah arkeologi Indonesia dan segenap pencapaiannya dimana sekalian kita saat ini menjadi bagian di dalamnya. Tak berlebihan rasanya jika kemudian ada yang bertanya, lantas akan dibawa kemana arkeologi Indonesia setelah usia seabad ini? Dimana arkeologi akan menempatkan diri memberi kontribusi bagi kehidupan berbangsa?

Sebagai penggiat pemula dalam studi arkeologi disadari bahwa kapasitas penulis jauh dari memadai untuk menjawab pertanyaan-pertanyaan di atas. Pun cakupan Kepurbakalaan Nusantara terlalu luas untuk dipahami. Hal yang paling mungkin untuk dilakukan adalah membuka ruang diskusi untuk bersama memadukan gagasan tentang arah dan peran studi arkeologi di Indonesia. Sebagai ajang tukar pendapat, tentu tidak semua pandangan akan selaras. Namun semangat untuk memajukan kepurbakalaan nasional kiranya mampu menjadi pengikat. Makalah sederhana ini merupakan upaya menciptakan ruang dimaksud.

Dengan ruang aktivitas yang selama ini juga terbatas di Kepulauan Maluku, akan lebih tepat kiranya jika kontribusi pemikiran penulis dalam diskusi, juga diletakkan pada kerangka geografis wilayah ini. Perhatian akan diberikan pada rekam historis studi arkeologis di Maluku yang menjadi landasan bagi karakter kepurbakalaan di Kepulauan ini. Selanjutnya akan ditinjau aktivitas studi arkeologis kontemporer untuk mengamati kontribusi arkeologi bagi kemajuan wilayah dan pengembangan masyarakat. Diskusi akan diakhiri dengan berupaya meninjau gagasan yang menjadi kemungkinan arah dan peran arkeologi di Maluku bagi tujuan akademis dan sosial di masa mendatang. Bercermin pada paparan di atas, maka permasalahan yang diajukan dalam makalah ini adalah, bagaimanakah profil historis penelitian arkeologi di Kepulauan Maluku dan seperti apa arah dan peran aktivitas ilmiah ini ke depan di wilayah ini?

\section{METODE}

Dengan kerangka telaah historis atas rekam penelitian serta diskusi tentang arah dan peran penelitian arkeologi, maka pendekatan yang digunakan dalam kajian ini adalah studi pustaka. Perhatian akan diberikan bagi referensi terkait rekam penelitian arkeologi yang telah dilakukan di Maluku serta kumpulan pustaka terkait studi sejarah budaya Maluku yang dipandang relevan dengan refleksi satu abad studi purbakala di Nusantara.

\section{HASIL DAN PEMBAHASAN}

\section{Cikal Bakal Studi Kepurbakalaan di Maluku: Era Kolonial}

Meski dengan cukup panjang tulisan ini dibuka dengan ulasan tentang mendiang Kempers, penulis belum pernah bertatap muka dengan sang tokoh arkeologi nasional. Pertautan dengan Kempers memang sudah dimulai di awal-awal masa kuliah arkeologi. Nama Kempers, menjadi bagian dari pengetahuan historis tentang perkembangan studi arkeologi di Indonesia. Pengenalan akan figur Kempers, baru menjadi lebih mendalam ketika penulis mulai bergabung dengan Balai Arkeologi Ambon. Ketika itu dalam salah satu penelitian di Kepulauan Tanimbar, tim menemukan fragmen nekara pejeng. Kajian atas temuan ini kemudian melekatkan pada salah satu sumbangan akademis terbaik Kempers bagi arkeologi Indonesia dan Asia Tenggara lewat bukunya The Kettledrums of Southeast Asia: A Bronze Age world and its aftermath (Kempers, 1988). 
Buah karya Kempers ini memang secara khusus mengulas tentang nekara sebagai produk budaya perunggu di Asia Tenggara. Bukan kebetulan, jika Maluku yang pernah menjadi rumah bagi setidaknya 12 nekara perunggu tipe Heger I, cukup banyak disinggung dalam buku ini. Termasuk, ihwal peran Rumphius yang menjadi penanda cikal bakal studi kepurbakalaan di Nusantara. Disebutkan bahwa sang ilmuwan mencatat tentang keberadaan benda-benda perunggu yang memiliki nilai magi bagi penduduk di Maluku. Beberapa spesimen nekara sempat dikumpulkan Rumphius dan dikirimkan ke Eropa (Kempers, 1988)

Aktivitas pengumpulan dan pencatatan Rumphius ini, kemudian ditulis dan diterbitkan dalam sebuah buku yang berjudul D’Ambonische Rariteit Kaamer (1705) atau Kamar Benda-Benda Antik dari Ambon (Ririmasse, 2005: 21). Karya akademis ini kemudian disepakati sebagai pustaka paling awal yang mengulas mengenai kepurbakalaan di Nusantara. Mendahului ulasan CA Lons tentang Candi Prambanan. Kehadiran buku ini juga sekaligus menjadi penanda dimulainya studi kepurbakalaan di Indonesia. Dengan karya ini Rumphius, yang datang sebagai serdadu bayaran VOC, menjelma menjadi salah satu ilmuwan Eropa paling awal yang beraktivitas di Nusantara.

Setelah Rumphius, ulasan tentang kepurbakalaan di Maluku lebih banyak hadir dalam bentuk catatan-catatan pendek dalam rekam perjalanan. Himpunan referensi semacam ini disumbangkan oleh individuindividu yang bertugas sebagai petugas militer kolonial, aparatur pemerintah, hingga misionaris. Hasil pengamatan yang ditulis umumnya masih melekat pada karakteristik yang serupa, berupa catatan tentang bendabenda unik-antik yang memiliki keterkaitan dengan mitologi dan kepercayaan masyarakat setempat (Ririmasse, 2011: 37-51).

Beberapa nama yang dapat disebut antara lain adalah, E.Chr. Barchewitz yang merekam keberadaan nekara di Pulau Luang dalam bukunya Ost-Indiansiche Reise-
Bescheribung (1730). Tahun 1881, seorang misionaris protestan N Rinooy, melaporkan keberadaan sebuah artefak perunggu, berupa 'lonceng' yang mirip dengan apa yang ditemukan di Leti. Nekara ini sempat hancur dalam kebakaran tahun 1917 dan fragmennya kemudian dibeli oleh Nieuwenkamp pada tahun 1918. Fragmen nekara ini kemudian dikirimkan ke Museum Batavia pada tahun 1937. Seorang petugas kolonial Rouffaer, juga sempat mencatat keberadaan nekara lain di Leti pada tahun 1918. Adalah Rouffaer yang berdasar pada kunjungan ini kemudian menulis surat kepada Museum Batavia dengan menekankan pentingnya perlindungan atas nekara-nekara kuna di propinsi terluar. "Pusaka nasional ini seharusnya tetap dijaga in situ, atau dikirimkan ke Museum Batavia. Tidak seorangpun seharusnya dijinkan membawa pergi benda-benda ini!" demikian tulisnya (Kempers, 1988: 412-413).

Pada penghujung abad ke-19 dan awal abad ke-20, ulasan tentang kepurbakalaan di Maluku masih datang dari catatan tentang artefak-artefak lepas seperti nekara. Tahun 1890 dua buah nekara ditemukan di pesisir tenggara Pulau Kur, Kepulauan Kei dan dilaporkan oleh G.W.W.C. Baron van Hoevell. Namun baru pada tahun 1934 benda-benda ini diambil oleh J. W. Admiraal dan diserahkan menjadi koleksi Museum Nasional. Di penghujung abad ke-19 muncul himpunan catatan mengenai keberadaan lukisan cadas di Desa Dudumahan, Kei Kecil. Tercatat nama-nama seperti Langen, van Hoevel dan Jacobsen mengulas mengenai situs ini. Pada awal abad ke-20 MacKellar dan Geurtjens mempublikasikan naskah mengenai situs lukisan cadas di Dudumahan. Umumnya informasi yang disajikan lebih menekankan pada jejak penguburan yang ditemukan di situs ini serta asal usul sesuai sejarah tutur masyarakat setempat mengenai lukisan ini (Ballard, 1988:139-161; Arifin dan Delanghe, 2004: 39).

Himpunan catatan awal tentang kepurbakalaan di Maluku dari abad ke -17 hingga permulaan abad ke-20 kiranya lebih 
mencerminkan minat individu-individu atas benda unik-antik yang memiliki nilai mitologi bagi masyarakat setempat. Belum ditemukan adanya ulasan yang mendalam yang dapat mencerminkan suatu pendekatan sistematis untuk mengkaji ragam artefak yang disebutkan. Tumbuh pada era kolonial, semua rekam awal kepurbakalaan di Maluku, disumbangkan oleh orang-orang Eropa yang bergiat di wilayah ini.

\section{Dekade Awal Penelitian Arkeologi}

Rekam kepurbakalaan di Maluku dalam kerangka akademis baru muncul pada tahun 1930-an melalui studi yang dilakukan oleh J. Roder. Ketika itu Roder menjadi bagian Ekspedisi Leo Frobenius ke Pulau Seram yang dipimpin oleh Doktor A. E. Jensen. Ekspedisi ini bertujuan melakukan penelitian etnologi dan prasejarah yang diprakarsai oleh Institut Penelitian Morfologi Kebudayaan dari Universitas Frankfurt am Main di Jerman. Dalam misi ini Roder merekam keberadaan situs-situs seni cadas di sepanjang aliran Sungai Tala. Lukisan cadas juga teridentifikasi di wilayah Teluk Saleman, di Pesisir Utara Pulau Seram. Roder mendeskripsikan pahatan dan lukisan yang ditemukan secara rinci. Termasuk teknik pembuatan, kondisi pahatan dan lukisan serta penafsiran atas makna figur yang ditampilkan. Temuan Roder ini kemudian dipublikasian di majalah Paideuma nomor satu dengan judul Felsbider Auf Ceram (Arifin dan Delanghe, 2004). Buah karya akademis Roder ini merupakan penanda dimulainya studi kepurbakalaan modern di Maluku.

Lepas penelitian Roder, studi arkeologis di Maluku vakum selama beberapa dekade. Baru pada tahun 1976 tim penelitian yang dipimpin Soegondho dan Bintarti melakukan survei arkeologis di pesisir selatan Pulau Seram. Dalam studi ini diidentifikasi situssitus gua di wilayah Amahai. Indikasi potensi prasejarah juga muncul dengan ditemukannya alat serpih bilah di situs Rohowa. Studi yang dilakukan Soegondho dan Bintarti ini merupakan studi perdana arkeolog nasional di Maluku.
Tahun 1970-an juga menandai kembalinya kelompok peneliti asing yang melakukan penelitian di wilayah Maluku. Tercatat nama-nama seperti Spriggs dan Miller (1988) yang melakukan survei penjajakan atas potensi arkeologis yang ada di wilayah Seram dan Kepulauan Kei. Dalam penelitian ini terekam situs-situs seperti Hatusua di Seram Barat; Nekara Heger di Vaan untuk pertama kali. Figur-figur seperti Ellen dan Glover (1979:353, 379) juga melakukan studi penjajakan di Pulau Seram dengan perhatian pada jejak alat litik di wilayah ini.

Geliat yang sempat muncul sepanjang tahun 1970-an ternyata belum berbanding lurus dengan perkembangan frekuensi studi arkeologis di wilayah ini. Maluku tetap menjadi salah satu wilayah yang paling minim mendapat perhatian hingga masa itu. Sepanjang tahun 1980-an aktivitas penelitian yang tercatat di wilayah ini hanya muncul dari studi yang dilakukan Ballard atas situs lukisan cadas di Dudumahan, Kepulauan Kei. Dalam penelitian ini Balard mengidentifikasi lebih dari 400 motif lukisan cadas dan berupaya menemukan penjelasan terkait asal muasal lukisan ini dalam konteks situs serupa di zona Laut Banda.

Baru pada tahun 1990-an studi arkeologis menemukan momentum kebangkitannya di Maluku menyusul rekam panjang studi arkeologis yang dilakukan selama dekade ini. Tercatat studi yang dilakukan oleh tim Universitas Hawaii dan Universitas Pattimura yang berupaya meninjau pemanfaatan gua; keragaman subsistensi serta kajian etnoarkeologi pada komunitas tradisional di Pulau Seram (Starks dan Latinis, 1992; Latinis dan Starks, 1998).

Pada era ini juga Pusat Arkeologi Nasional melakukan studi arkeologis di wilayah Tehoru, di Pesisir Selatan Pulau Seram yang dipimpin oleh Soegondho dan Bintarti. Studi juga dilakukan oleh Intan dan Istari (1995) dalam mengamati situs lukisan cadas di Dudumahan, Kepulauan Kei. Intan juga mengidentifikasi dan merekam keberadaan monumen perahu batu di Situs Sangliat Dol (1994) 
Catatan penelitian terpenting di Maluku selama era 1990-an diwakili oleh studi tiga musim 1995-1997 di Kepulauan Aru yang merupakan buah kerjasama Pusat Arkeologi Nasional dan Universitas Nasional Australia. Fokus penelitian ini diarahkan pada beberapa isu sentral seperti jejak kolonisasi maritim dan awal penghunian serta koneksitas antar pulau pada masa Plestosen dan awal Holosen; Jejak pertanian dan domestikasi hewan serta interaksi antara pemukim awal dan pemukim Austronesian, peran Kepulauan Aru sebagai pemasok bulu burung cendrawasih dan ragam produk hutan dan laut dalam kurun 2000 tahun. Hasil penelitian tiga musim ini telah diterbitkan dalam The Archaeology of Aru Islands, Eastern Indonesia (O'Connor et.al, 2005: 19; Flanery dan White, 1991:96-113; Gelpke, 1994:123-145; Heinsohn, 2010: 38-91; Jelsma,1999:41-45; Liley, 1992:150-171; Mahmud, 2009:34; Miedema ,1997:18; Pasveer, 1998:67-89; Prasetyo, 2009:34-48).

Tahun 1999-2002 Maluku dilanda konflik sosial. Ekses atas kejadian ini juga menyentuh ranah penelitian arkeologi. Ketika hampir satu dekade, Maluku tertutup untuk peneliti nasional dan asing. Aktivitas studi arkeologis selama masa tanpa kepastian ini dilakukan oleh Balai Arkeologi Ambon yang ketika itu belum lama dibentuk dan langsung harus menghadapi aktivitas riset dalam kondisi wilayah yang belum stabil.

\section{Lembaga Penelitian untuk Kepulauan Maluku: Balai Arkeologi Ambon}

Balai Arkeologi Ambon didirikan pada tahun 1995. Lembaga ini merupakan Unit Pelaksana Teknis dari Kementerian Pendidikan dan Kebudayaan. Pendirian lembaga ini ditujukan untuk melaksanakan penelitian arkeologi di wilayah Maluku dan Maluku Utara. Balai Arkeologi Ambon merupakan satu dari sepuluh lembaga serupa yang tersebar di seluruh Indonesia. Dengan pembagian ini diharapkan, aktivitas studi arkeologi di Indonesia dapat lebih efektif dan memberikan hasil yang komprehensif.
Kondisi geografis Maluku sebagai wilayah kepulauan dengan luas perairan mencapai sembilan puluh persen dengan jumlah pulau lebih dari seribu, merupakan tantangan alami yang harus dihadapi dalam proses riset. Hal ini yang kemudian menjadi salah satu pertimbangan dibentuknya lembaga riset arkeologi yang secara khusus menangani wilayah ini.

Demikian halnya dengan keletakan Maluku secara biogeografi yang berada di Zona Wallacea, merupakan pertimbangan kunci lainnya yang membuat wilayah ini perlu untuk dikaji secara mandiri dalam satu kerangka ruang. Profil ekologi yang kompleks merupakan determinan dalam menciptakan proses budaya yang raya. Dengan karakteristik sejarah budaya yang khas ini, membuat Maluku menjadi wilayah yang perlu dikelola secara khusus dalam kerangka studi arkeologi.

Semenjak didirikan hampir dua dekade silam, tema penelitian utama atau highlight di Balai Arkeologi Ambon memang dilekatkan pada arkeologi kolonial. Pertimbangan pemilihan tema ini agaknya melekat dengan kenyataan bahwa Kepulauan Maluku secara historis menyatu dengan sejarah rempah dan awal kolonialisme. Hal mana dapat diamati dari produk-produk budaya era kolonial yang bertebaran secara luas di kepulauan ini. Maluku merupakan salah satu wilayah di Indonesia dengan sebaran benteng Eropa terbanyak. Disayangkan, bahwa meski telah ditetapkan sebagai tema besar penelitian kawasan, saat itu tidak dijabarkan secara rinci aspek-aspek yang menjadi tujuan dan sasaran riset dalam kurun waktu yang terukur. Hasilnya, arkeologi kolonial di Maluku hingga saat ini belum memberikan temuan dan konsep yang mencerminkan nilai pentingnya sebagai tema unggulan.

Sejatinya selain tema kolonial, Maluku juga memiliki potensi yang jauh lebih kompleks pada tema-tema lain seperti arkeologi Islam dan Prasejarah. Kepulauan ini merupakan rumah bagi beberapa kerajaan Islam awal di Nusantara seperti Ternate 
dan Tidore yang menjadi mercusuar bagi penyebaran Islam di kawasan timur Nusantara. Arkeologi Prasejarah juga merupakan prospek. Menimbang peran Maluku sebagai bagian dari Wallacea, kawasan dengan karakteristik ekologi yang khas. Demikian pula keletakan kepulauan ini yang berada antara Asia dan Australia memiliki peran kunci dalam upaya menjelaskan proses kompleks migrasi manusia masa lalu.

Berpijak pada kondisi di atas, dimana profil sejarah budaya yang kompleks jalin menjalin dengan bentang luas geografi kawasan, membuat upaya untuk mengelola studi arkeologi di Maluku menjadi suatu tantangan. Penentuan prioritas tema penelitian dan aspek-aspek kunci yang dikaji menjadi penentu dalam upaya menciptakan strategi riset efektif dengan hasil maksimal.

Tak lama setelah Balai Arkeologi Ambon didirikan, Pusat Penelitian dan Pengembangan Arkeologi Nasional (kini Pusat Arkeologi Nasional) sebagai instansi induk sebenarnya telah menciptakan panduan tematis terkait aspek-aspek yang menjadi rujukan bersama penelitian arkeologi nasional. Dikenal sebagai Rencana Induk Penelitian dan Pengembangan Arkeologi Nasional (RIPAN), konsep ini memuat tujuh tema kunci yang memberi arah bagi penelitian arkeologi di Indonesia untuk mencapai sasaran komprehensif yang berskala nasional. Pemilihan tema dan aspek yang dikaji, menyesuaikan dengan kondisi potensi dan karakteristik wilayah kerja pada setiap lembaga.

Dalam perjalanannya, terbukti RIPAN mampu menjadi template kolektif yang memandu arah penelitian arkeologi nasional dimana aktivitas studi arkeologis yang dilakukan Pusat Arkeologi Nasional dan Balar-Balar kini memiliki benang merah yang jalin menjalin secara konseptual. Hasil pada setiap wilayah kerja tentu berbeda, dalam hal luasan aspek yang ditinjau dan kedalaman serta bobot pastilah bervariasi antara satu unit kerja dengan unit kerja lainnya. Hal yang kemudian disayangkan adalah bahwa dengan progres positif tersebut, skema besar yang terwakili dalam RIPAN agaknya tidak pernah benar-benar ditinjau proses dan capaiannya secara komprehensif. Termasuk dalam lingkup Balai Arkeologi Ambon. Aktivitas penelitian terus berjalan. Setia dalam koridor rutinitas. Karenanya meski selintas, hal dimaksud akan coba diamati.

Sejauh ini bercermin pada rekam penelitian yang telah dilaksanakan, isu-isu yang dicakup selama hampir dua dekade pada setiap periodisasi di Balai Arkeologi Ambon dapat dibagi menurut beberapa kelompok. Isu kolonial sebagai highlight tentu mendominasi dengan aspek-aspek yang ditinjau antara lain: kontak dan interaksi awal dengan para pendatang Eropa; proses awal kolonisasi dan dampak sosialnya; ekonomi kolonial: perdagangan dan monopoli rempah; materialisasi proses kolonisasi: jejak monumental kolonial; arkeologi kota kolonial. Arkeologi Islam sebagai periodisasi yang juga bertautan dengan struktur sosial yang relatif kompleks memiliki keragaman yang kurang lebih serupa dengan masa kolonial. Dimana aspek-aspek yang ditinjau dalam rekam studi arkeologi di Maluku mencakup setidaknya isu seperti: masuk dan berkembangnya Islam di Maluku; proses pelembagaan institusi Islam; materialisasi budaya Islam; Islam dalam jejak tradisi.

Prasejarah sebagai ranah studi yang paling luas bentang waktu dan potensinya, ternyata bisa dikatakan justru belum memberikan kontribusi maksimal dalam wajah arkeologi Maluku. Hal mana tergambar lewat cakupan kajian yang umumnya melekat pada pendekatan eksploratif dengan aspek-aspek yang belum berbanding lurus dengan potensi prasejarah Maluku secara kawasan. Skala studi yang didominasi situs mikro; kaburnya landasan konseptual yang mendasari setiap kajian; minimnya pertautan dengan isu-isu berskala kawasan dan regional; kaburnya arah penelitian yang bersifat strategis dalam jangka panjang; serta bobot penelitian yang masih jauh dari ideal merupakan parameter yang menjadi tolak ukur akan kondisi dimaksud. 
Diamati secara kronologis maka dapat dilihat bahwa aktivitas studi yang berkiblat pada upaya menemukan jejak-jejak budaya tertua yang diwakili oleh teknologi Paleolitik hingga saat ini belum dilakukan oleh Balai Arkeologi secara mandiri. Pengamatan pada jejak Paleolitik dalam konteks Maluku secara kawasan diwakili oleh hasil penelitian asing dan nasional. Kondisi serupa kiranya juga ditemukan dalam konteks kajian-kajian yang melekat pada budaya Neolitik. Identifikasi situs-situs yang ditautkan dengan proses migrasi penutur bahasa Austronesia ini juga merupakan sumbangsih para peneliti asing yang aktif di Maluku. Adalah dalam konteks masa prasejarah akhir Balai Arkeologi Ambon memiliki kontribusi riil bagi pengetahuan kawasan. Sebagaimana dengan terwakili dalam identifikasi ragam temuan-temuan baru berciri budaya perunggu-besi yang tersebar di wilayah ini.

Tema yang bertautan dengan jejak budaya prasejarah dimana Balai Arkeologi memiliki rekam jejak penelitian mandiri kiranya lebih diwakili oleh aspek yang menautkan budaya prasejarah dalam bentuk tradisi berlanjut. Dalam konteks ini, kondisi dimaksud diwakili oleh jejak budaya megalitik yang masih luas ditemukan dalam keseharian masyarakat di wilayah Kepulauan ini. Praktekpraktek budaya lokal yang mencerminkan cara hidup lampau juga menjadi aspek yang dikaji dalam kerangka etnoarkeologi. Pada ranah ini, hasil studi mandiri di Balai Arkeologi Ambon cukup luas. Kekayaan potensi etnogafi di Maluku menjadi aspek kunci yang memberi impak positif bagi etnoarkeologi.

Disamping rangkaian isu yang melekat pada kerangka kronologi di atas, terdapat himpunan tema lain yang dikembangkan secara mandiri dalam konteks penelitian di Balai Arkeologi Ambon. Beberapa isu yang mengemuka dan terus dikembangkan selama empat tahun terakhir ini antara lain diwakili oleh studi arkeologi di kawasan tapal batas dan pulau-pulau terdepan; arkeologi maritim; arkeologi kepulauan dan kawasan pesisir; serta Cultural Resources Management atau CRM dengan perhatian pada kontribusi arkeologi untuk pendidikan lokal. Meski himpunan tema spesifik ini masih dalam tahap inisiasi; namun orisinilitas gagasan yang selaras dengan karakteristik dan potensi kawasan yang berciri arsipelago, kiranya memberi kondisi yang cukup menjanjikan untuk pengembangan ke depan.

\section{Kepulauan Maluku: Hasil Penelitian Penting dan Situs Unggulan}

Sebagai disiplin yang berupaya menjelaskan proses sejarah budaya dalam kerangka waktu; aspek pertanggalan atau kronologi kiranya menjadi elemen kunci yang memberi bobot bagi hasil penelitian. Adalah pertanggalan dalam kaidah ilmiah yang kemudian menjadi rujukan bagi arkeologi untuk menjelaskan kompleksitas dinamika peradaban manusia dalam bentang masa yang terukur. Tak heran bila berbicara mengenai hasil penelitian penting yang mencerminkan capaian suatu proses studi arkeologis, maka aspek pertanggalan senantiasa harus dikedepankan.

Meski rekam aktivitas penelitian di Maluku telah berbilang lebih dari setengah abad, dengan intensitas yang bisa dikatakan meningkat dalam kurun dua dekade terakhir, rekam pertanggalan pada situs-situs arkeologi di Kepulauan Maluku bisa dibilang sangat minim. Penelusuran yang dilakukan pada segenap rekam penelitian yang telah dilaksanakan di wilayah ini menunjukan bahwa seluruh rekam pertanggalan yang ada merupakan kontribusi dari para peneliti asing yang pernah aktif di wilayah ini. Para peneliti nasional dan lokal yang melakukan studi arkeologi di Maluku, belum memiliki rekam aktivitas pertanggalan kronologi mandiri.

Rekam kronologi tertua di Kepulauan Maluku sejauh ini ditemukan di Kepulauan Aru dengan penanggalan pada angka 43000 TYL (tahun yang lalu). Angka ini merupakan hasil penelitian kolaborasi antara para peneliti Indonesia dan Australia dalam proyek berjudul Arkeologi Kepulauan Aru pada tahun 19951997 dan telah diterbitkan dalam sebuah monografi. Rekam penanggalan tertua lain juga 
disumbangkan oleh peneliti asal Australia, di wilayah Maluku Utara; sebagaimana dicuplik pada situs Goa Golo di Pulau Gebe Maluku Utara yang memiliki angka penanggalan hingga 31000 TYL. Kedua situs ini adalah lokus dengan rekam penanggalan paling awal yang ditemukan di Maluku. Hal mana yang kemudian memberi nilai penting bagi peran kedua situs ini sebagai mercusuar kronologi di Kepulauan Maluku.

Dalam konteks produk budaya menurut tinjauan bentang waktu maka jejakjejak budaya spesifik yang ditemukan di wilayah Maluku juga memiliki keragaman raya. Dimulai dari budaya Paleolitik hingga kini baru teridentifikasi di beberapa titik di Kepulauan Maluku. Jejak Paleolitik dengan penanggalan tertua terekam di Kepulauan Aru dan Gua Golo di Gebe (Belwood, 2000:228259), Maluku Utara. Pada kedua titik ini, aktivitas pada jaman batu tua teridentifikasi di situs dengan ciri hunian gua. Hal yang layak menjadi perhatian adalah kenyataan bahwa hingga saat ini, rekam kronologi dengan setting budaya paleolitik belum ditemukan di pulau-pulau di wilayah Maluku Bagian Tengah. Nihil pada pulau seperti Seram yang memiliki profil geologi tertua dibanding pulaupulau lain yang ada di Maluku. Indikasi jejak budaya Paleolitik di Seram, sejauh ini baru diwakili oleh temuan permukaan himpunan alat batu dari masa dimaksud di beberapa titik daerah aliran sungai di sepanjang Pesisir Utara Pulau Seram. Kondisi yang masih harus ditindaklanjuti dengan upaya untuk menemukan bukti-bukti budaya tertua tersebut dalam konteks arkeologis.

Bergerak ke masa yang lebih muda, Maluku juga terbilang sebagai wilayah sebagai sebaran situs berkarakter neolitik yang mininal. Kondisi ini tentu menjadi catatan tersendiri menimbang wilayah lain dalam konteks kawasan seperti Oseania di timur dan Sulawesi di sebelah barat memiliki rekam situs-situs neolitik yang cukup kompleks. Kondisi ini kiranya terkait dengan minimnya aktivitas penelitian dengan basis budaya neolitik di wilayah ini. Situs neolitik dengan produk budaya dan kronologi yang meyakinkan sejauh ini baru ditemukan di setidaknya dua titik di Maluku. Pertama, adalah situs Uattamdi di Kayoa Maluku Utara dan kedua, situs Pulau Ay 1 di Kepulauan Banda. Di Kayoa rekam kronologi menunjukkan angka hingga 3200 TYL sementara di Pulau Ay, penarikhan sejauh ini telah mencapai angka 3200 TYL (Lape, 2010: 62-7).

Adalah situs-situs dengan karakteristik budaya masa logam awal dari era prasejarah akhir yang kiranya memiliki sebaran cukup luas di wilayah Maluku. Tercatat setidaknya lebih dari selusin situs yang memiliki rekam penanggalan dan jejak budaya pada masa peralihan ke sejarah ini. Di wilayah Maluku Utara terdapat himpunan situs dengan indikasi temuan berciri Masa Logam Awal dengan kisaran waktu sekitar 2000 TYL. Wilayah Maluku Tengah sebagai kawasan dengan penanggalan arkeologis yang sangat minimal, memiliki catatan kronologi atas situs masa prasejarah akhir sebagaimana diwakili oleh jejak budaya hingga 1000 tahun silam di situs Hatusua di pesisir barat Pulau Seram. Di wilayah pulau-pulau terselatan, meski belum memiliki rekam pertanggalan yang sahih, namun kawasan ini merupakan wilayah dengan sebaran nekara perunggu terbanyak di Maluku. Setidaknya dari 13 nekara perunggu tipe Heger 1 yang lekat dengan budaya Dong Son, 12 spesimen di antaranya ditemukan di wilayah pulau-pulau di selatan Maluku. Kondisi yang kiranya dapat menjadi cermin akan potensi wilayah ini dalam upaya menjelaskan dinamika kawasan di masa peralihan menuju era sejarah.

Masih dalam lingkup geografis pulau-pulau di belahan selatan Kepulauan Maluku, hasil penelitian berciri prasejarah yang dipandang memiliki nilai penting secara kawasan ditemukan di Kepulauan Tanimbar. Di sini, dalam studi yang dilakukan selama empat tahun terakhir, telah mengidentifikasi sejumlah titik baru dari situs dengan temuan unggulan berupa pemukiman kuna dengan elemen kunci monumen perahu batu. Sebelumnya hanya teridentifikasi dua titik pemukiman yang 
memiliki monumen dengan spesifikasi khas ini di Tanimbar. Hasil studi selama empat musim kini telah memberikan gambaran baru tentang setidaknya lima titik baru situs serupa dalam kawasan. Kondisi ini kiranya dapat menjadi gerbang untuk mendapatkan penjelasan ilmiah yang lebih mendalam tentang peran elemen sentral ini dalam rekayasa ruang tradisional di Kepulauan Tanimbar yang diperkirakan berkembang di era protosejarah.

Hasil studi lain yang layak untuk dikedepankan adalah terkait diaspora nekara perunggu dan produk budaya Dong Son di Kepulauan Maluku. Meski berada dalam cakupan geografis yang bisa dikatakan zona terluar Kepulauan Asia Tenggara, Kepulauan Maluku ternyata merupakan rumah bagi setidaknya lebih dari selusin nekara Dong Son tipe Heger I. Termasuk salah satu temuan terbaru yang diidentifikasi pada awal tahun 2014 di Kepulauan Tanimbar. Dengan jumlah mencapai 13 spesimen, Maluku adalah wilayah dengan populasi temuan nekara Dong Son Tipe Heger I terpadat di Nusantara setelah Jawa. Menarik bahwa dari jumlah tersebut 12 spesimen ditemukan di wilayah Kepulauan Maluku Tenggara. Hal mana yang meletakkan dasar akademis bagi keharusan pengembangan aktivitas studi terkait tema khas ini di wilayah yang paling minim disentuh studi arkeologis selama ini.

Segenap hasil penelitian dengan aspek dan situs-situs unggulan di atas kiranya adalah catatan kinerja arkeologi di wilayah Kepulauan Maluku selama kurun waktu lebih dari dua dekade terakhir. Hal yang kemudian menjadi cermin bahwa gambaran atas wajah arkeologi di Maluku agaknya masih jauh dari yang diharapkan. Kenyataan bahwa Maluku merupakan wilayah dengan potensi raya, belum berbanding lurus dengan hasil penelitian. Kondisi yang kemudian sewajarnya menjadi pendorong bagi arkeologi untuk meningkatkan rekam kinerja di wilayah ini.

Hal yang juga perlu menjadi perhatian bersama adalah implikasi rekam aktivitas penelitian yang telah dilakukan beserta segenap hasilnya bagi pengembangan daerah.
Hadir sebagai satu-satunya lembaga berbasis riset untuk arkeologi, pada Balar juga melekat tanggung jawab untuk mendayagunakan segenap hasil penelitian untuk kemajuan wilayah kerja. Sejauh ini dalam konteks Balai Arkeologi Ambon daya guna himpunan hasil studi arkeologi yang telah dilaksanakan kiranya dapat diamati dari beberapa aspek: pertama, penguatan pengetahuan sejarah lokal untuk pengembangan muatan lokal untuk pendidikan. Kedua, penguatan identitas dalam konteks keberagaman; ketiga, pengayaan potensi budaya daerah dan pengembangan sistem tata-kelola pusaka; keempat, pengembangan untuk tujuan pariwisata; kelima terbentuknya basis data pengetahuan arkeologi dan sejarah budaya yang menjadi rujukan pengembangan wilayah dalam arti seluas-luasnya termasuk skema rencana tata-ruang; kebijakan tatakelola pemerintahan dan masyarakat lokal; pelestarian lingkungan dan tata kelola bencana.

\section{KESIMPULAN}

Lebih dari seabad arkeologi telah menjadi bagian utuh dari tata-kelola negara. Lahir dan bertunas di era kolonial, arkeologi nasional tumbuh dan mendewasa dengan segala dinamika. Dari lembaga kecil dengan cakupan kerja terbatas, berkembang menjangkau hampir seluruh pelosok Nusantara. Dalam laju kemajuan tersebut, peran dan manfaat segenap aktivitas studi dan hasilnya masih terus menjadi pertanyaan. Adakah arkeologi telah mampu memberi kontribusi sesuai potensi dan kapasitasnya bagi bangsa dalam arti seluasya?

Sebagai bagian arkeologi nasional, Balai Arkeologi juga dihadapkan pada tantangan serupa. Hadir sebagai garda depan studi kepurbakalaan di wilayah kerja, Balai Arkeologi dituntut untuk mampu memberi kontribusi riil bagi pengembangan dan kemajuan daerah. Baik dalam ranah akademis, namun diharapkan meluas hingga menyentuh aspek sosial dan kemasyarakatan. Dalam konteks Balai Arkeologi Ambon, rekam studi yang dilakukan selama lebih dari dua dekade telah memberikan suatu kerangka pengetahuan terkait kepurbakalaan dan sejarah budaya di 
Kepulauan Maluku. Membentang dari masa prasejarah hingga dinamika di era kolonial. Catatan tentang keterbatasan dan kendala tentu ada. Hal mana semestinya menjadi panduan untuk segenap rencana pengembangan studi arkeologi ke depan.

Menjadi pekerjaan rumah bersama adalah, segenap pengetahuan dimaksud sejatinya akan lebih memiliki makna jika mampu dikelola sedemikan rupa untuk memberi dampak bagi pengembangan daerah dan manfaat sosial bagi masyarakat. Upaya awal sudah mulai dilaksanakan sebagai telah disampaikan dalam paparan pendek di atas. Harapannya tentu saja agar itu semua dapat terus dikembangkan, sehingga arkeologi mampu menjadi disiplin yang secara aktif berperan mendorong Kepulauan Maluku ke arah yang lebih baik

\section{$* * * * *$}

\section{DAFTAR PUSTAKA}

Arifin, Karina dan Philippe Delanghe. (2004). Rock art in West Papua, Italia: UNESCO.

Ballard, C. (1988). Dudumahan: A rock art site on Kai Kecil, Southeast Mollucas. Bulletin of the Indo-Pacific Prehistory Association, 8, 139-161.

Bellwood, Peter. (2000). Prasejarah kepulauan Indo-Malaysia. Jakarta: PT. Gramedia Pustaka Utama.

Bulmer, S dan Bulmer, R. (1964). The prehistory of the Australian New Guinea Highlands. J. B. Watson (Ed.) New Guinea: the Central Highlands, 39-76. American Anthropologist 66.4, Part 2 Special Publication.

Ellen, R. F dan Glover, I. C. Pottery Manufacture and Trade in the Central Moluccas, Indonesia: the Modern Situation and the Historical Implications. Man n.s, 9, 353-379.

Flannery, T. and White, P. (1991). Animal Translocations. National Geographic Research and Exploration 7, 96-113.

Gelpke, S. (1994). The report of Miguel Roxo de Brito of his voyage in 1581-2 to Raja Ampat, the MacCluer Gulf and
Seram. Bijdragen tot de Taal-, Land- en Volkenkunde, 150, 123-145

Heinsohn, T.E. (2010). Marsupial as

introduced species: Long-term anthropogenic expansion of the marsupial frontier and its implications for zoogeographic interpretation. Terra Austrialis 32: Altered Ecologies: Fire, climate and human influence on terrestrial landscapes. Canberra: ANU Press.

Jelsma, J. (1999). Room with a view: An excavation in Toe Cave, Ayamaru District, Bird's Head, Irian Jaya Indonesia. Modern Quaternary Research in Southeast Asia, 15, 41-45.

Kempers, Bernet AJ. (1988). The Kettledrums of Southeast Asia. Rotterdam: A.A Balkema. Kempers, A.J. Bernet. (1978). Herstel in Eigen Waarde; Monumentenzorg in Indonesie. Amsterdam: De Walburg Pers Zutphen.

Lape, P.V. (2000)a. Contact and Conflict in the Banda Islands, Eastern Indonesia, 11th to 17th Centuries. Rhode Is land: Brown University. Lape, P.V. (2000)b. Political dynamics and religious change in the late precolonial Banda Islands, Eastern Indonesia. World Archaeology, 32(1), 138-55.

Lape, P.V. (2000)b. Political dynamics and religious change in the late pre-colonial Banda Islands, Eastern Indonesia. World Archaeology, 32(1), 138-55.

Lape, P. (2006). Chronology of fortified sites in East Timor. Journal of Island and Coastal Archaeology, 1, 285-297.

Lape, P. (2010). Paleoclimates and emergence of fortification in the tropical Pacific islands. Journal of Anthropological Arcaheology, 29(1).

Latinis, D.Kyle and Ken Stark. (1998). Subsistence, Arboriculture and Prehistory in Maluku. Old World Places, New World Problems, 34-65. Canberra: Center for Resources and Enviromental Studies.

Lilley, I. (1992). Papua New Guinea's Human Past: the Evidence in Archaeology dalam R.D Attenborough dan M.P Alpers (eds.) Human Biology in New Guinea: the Small Cosmos, 150-171. Oxford: Clarendon Press. 
Mahmud, I. (2009). Pernak-pernik penelitian arkeologi di Papua. Papua, 1(2).

Miedema, J et al. (1997). Perspectives on The Bird's Head of Irian Jaya, Indonesia. Proceedings of The Conference, Leiden 1317 Oktober 1997. Amsterdam: Rodopi B.V.

Pasveer, J.M. (1998). Kria cave: an 8000year occupation sequence from Bird's Head of Irian Jaya. Modern Quaternary Research in Southeast Asia, 15, 67-89.

Prasetyo, Bagyo. (2009). Perkembangan hasil penelitian arkeologi di Tanah Papua. Seminar Perspektif Budaya Melanesia dan Austronesia dalam Dinamika Kebangsaan dan Pembangunan, dalam rangka Semarak Arkeologi 2009, di Jayapura Papua, 3-4 Juni 2009.

Ririmasse, M. (2005). Jejak dan Prospek Penelitian Arkeologi di Maluku. Kapata Arkeologi, 1(1).

Ririmasse, M. (2007). Fragmen Moko dari Selaru: Temuan Baru Artefak Logam di Maluku. Berita Penelitian Arkeologi, 3(5).

Ririmasse, M. (2008). Visualisasi Tema Perahu dalam Rekayasa Situs Arkeologi di Maluku. Naditira Widya, 2(1).

Ririmasse, M. (2010). Boat Symbolism and Identity in the Insular Southeast Asia: ACase Study from the Southeast Moluccas. Tesis Pascasarjana. Tidak diterbitkan. Leiden: Rijkuniversiteit Leiden.

Ririmasse, M. (2010). Arkeologi PulauPulau Terdepan di Maluku: Sebuah Tinjauan Awal. Kapata Arkeologi, 6(10).

Ririmasse, M. (2011). Koleksi Budaya Bendawi Maluku Tenggara di Museum Etnologi Nasional Leiden. Kalpataru, 20(1).

Sollewijn, Gelpke. (1994). The Report of Miguel Roxo de Brito of his Voyage in 1581-2 to the Raja Ampat, the MacCluer Gulf and Seram. BIjdragen tot de Taal Land en Volkenkunde, 150, 123-145.

Spriggs, M. (1998). Research questions in Maluku archaeology. Cakalele, 9, 49-62.

Spriggs, M. (1997). The Archaeology of the Bird's Head in it's Pacific and and Southease Asian Context in.
Spriggs, M. \& D. Miller. (1988). A previously unreported bronze kettledrum from the Kai Islands, eastern Indonesia. Indo-Pacific Prehistory Association Bulletin, 8, 79-88.

Starks, Ken, and D. Kyle Latinis. (1992). The Archaeology of Sago Economies in Central Maluku: An initial sketch. Cakalele, 3, 69-86.

Suroto, H. (2010). Prasejarah Papua. Denpasar: Udayana University Press.

Swantoro, P. (2002). Dari Buku ke Buku: Sambung Menyambung Menjadi Satu. Jakarta: KPG Gramedia.

Tanudirdjo, D. (2005). The Dispersal of Austronesian-speaking People and the Ethnogenesis of Indonesian People. Austronesian Diaspora and the Ethnogeneses of People in Indonesian Achipelago. Jakarta: LIPI Press.

Tanudirdjo, D. (2009). Interaksi Austronesia Melanesia: Kajian Interpretasi Teoritis. Seminar Perspektif Budaya Melanesia dan Austronesia dalam Dinamika Kebangsaan dan Pembangunan. Semarak Arkeologi 2009, di Jayapura Papua, 3-4 Juni 2009.

O'Connor, S., Spriggs, M. Veth, P. (2005). The Aru Island in Perspective dalam O'Connor, Sue et.al. The Archaeology of the Aru Island. Canberra: Pandanus Books. 